\title{
Review
}

\section{After injury: A historical anatomy of forgiveness, resentment, and apology}

\author{
Ashraf H. A. Rushdy \\ New York, Oxford University Press, 2018, 304 pp., \\ ISBN: 9780190851972
}

Contemporary Political Theory (2020) 19, S41-S43. https://doi.org/10.1057/s41296018-0270-z; published online 20 October 2018

Ashraf H. A. Rushdy's After Injury: A Historical Anatomy of Forgiveness, Resentment, and Apology provides a necessary supplement to the literature on forgiveness and apology, by including the interrelated phenomena of resentment and by contextualizing all three terms in European and American intellectual history. With clear exposition, he creates a conversation in which people can explore salient questions like: Is forgiveness always possible? Is it necessary to hold onto resentment to seek certain forms of justice? Why do some apologies cause more harm than good?

The book is divided into three sections: forgiveness, resentment, and apology. In the first section, Rushdy argues that modern, secular philosophical accounts are indebted to two Christian models of forgiveness. In chapter one, he boldly claims that Christianity has supplanted Jesus' model of forgiveness with a less appealing version presented by the biblical writer Paul. It should be noted here that some scholars will disagree with Rushdy's reading of Pauline literature, a reading that cannot be fully supported in a short chapter. Nonetheless, this polemical account fuels the compelling observation that contemporary scholarship overlooks a major division at the level of assumptions. In chapter two, Rushdy shows that three philosophers who otherwise disagree about what forgiveness means (John Milbank, Vladimir Jankélévitch, and Jacques Derrida) all come to the conclusion that forgiveness is impossible - beyond human capacity - because they all rely, if only implicitly, upon the Pauline model. In chapter three, the author lays out a debate between those he calls retributivists (Herbert Morris and Jeffrie Murphy feature prominently) and unconditionalists (especially Margaret Holmgren). This debate revolves around the question of whether forgiveness requires repentance. However, Rushdy's point is not to answer that question. Rather, he outlines this debate to reveal that both sides find that forgiveness is possible in accordance with the second

(c) 2018 Springer Nature Limited. 1470-8914 Contemporary Political Theory Vol. 19, S1, S41-S43 
model introduced in chapter one. In this model, taught by Jesus, forgiveness is merely - but efficaciously - human.

Rushdy's most impactful contribution may be the book's second section on resentment, in which the method is genealogy. In chapter four, he presents a twofold understanding of resentment, along with references to Dostoevsky's Notes from the Underground and an exposition of Sophocles' play Philoctetes. In chapter five, he explains that resentment belongs to the domain of individual conscience, through an engagement with eighteenth-century British moral philosophers Joseph Butler and Adam Smith. In chapter six, we see that resentment also can be an existential condition of society, as nineteenth-century Continental philosophers Søren Kierkegaard, Friedrich Nietzsche, and Max Scheler claimed. The former tradition saw resentment opening people up to the demands of justice, while the latter saw people closing in on themselves in self-conscious anguish. Over a hundred years in Europe, the discourse of resentment 'shifted from umbrage to envy' and from a personal 'animation of spirit' to a 'collective malaise' (p. 151). Yet, both sets of meanings survive in practice today.

Recovering the history of the term resentment gives people resources for a more complex approach to this intense emotional state. For instance, a two-fold understanding of resentment sheds light on (to use Katherine Cramer's phrase) 'the politics of resentment' and its role in the election of Donald Trump. For those who have focused on the violent, self-promoting anger of some Trump supporters, Rushdy has provided language with which to speak also about their perceived need for self-defense. For scholars who have focused on the legitimate concerns of those suffering losses due to globalization and urbanization, Rushdy provides a theoretical lineage for the connections between resentment and the hatred of the other. The current political moment, in which right-wing populism is globally on the rise, demands an appreciation for both forms of resentment.

As for apology, in the third section, Rushdy writes about the confusion fomented when we fail to distinguish between public and private apologies. He asks why so many public apologies seem to fail or to produce counter-productive effects. The answer, and a major theme of the book, is that people do not sufficiently account for the working assumptions that shape the meaning and efficacy of practices. Too often there is a disconnect between what we think apology is (or should be) and the possibilities of a particular relational landscape. In chapter seven, the author explores these themes with the American film Unforgiven (1992) directed by Clint Eastwood and the German film The Lives of Others (2006) directed by Florian Henckel von Donnersmarck. Chapter eight focuses on private apologies, comparing ordinary language philosopher J.L. Austin and sociologist Erving Goffman, then offering their insights as corrections to contemporary theories. Chapter nine focuses on public apologies, offering a typology of (1) celebrity apologies, (2) corporation apologies, (3) diplomacy apologies, (4) regime apologies, (5) court apologies, and (6) apologies for the past. 
After Injury provides a textured intellectual history of forgiveness, resentment, and apology to demonstrate that these three terms necessarily have pluriform meaning. This supports the book's conclusion that it would be better to forego extended definitional debates for developing more adept contextual analysis. Given this emphasis on context, it is disappointing that Rushdy does not articulate his own intellectual social location, or provide a rationale for his choices of texts and films. The writing is multi-disciplinary and well-laden with footnotes that can guide further investigations. Still, the reader is not given the navigational tools to fully appreciate the scope of the intervention. (Needless to say, as with every intellectual history, there are many perspectives missing.) This lack of orientation may not have been so lamentable were it not for the additional methodological choice to limit the use of case studies with which the reader is likely to have familiarity. Beyond brief references to headline news events, the book is a series of close readings of texts and films. While deep in those details, it can be difficult to recall the overall aim of enriching contemporary practices related to forgiveness, resentment, and apology. A second outcome of the choice regarding case studies is that we never see the 'interactive dynamic' of the three terms, even though their inevitable interdependence in meaning and efficacy is one of the author's key theoretical points (p. 18).

Who should read this book? It will be edifying to a wide range of academics interested in these topics who have been waiting for a long conversation with a well-read, thoughtful guide. Frankly, given the acute need for these practices in a time fraught with violence and contempt, other scholars will be frustrated with the pace and the 'relevance' of this book. However, it may be for them as well. I take it that one of Rushdy's objectives is to give pause to those who read and write books that answer the question 'what do we do now?' in simple terms.

Heather M. DuBois

Florida State University, Tallahassee, FL 32306, USA

hdubois@fsu.edu 